\title{
Analisis Perbandingan Aturan Penghapusan dan Pencegahan Kekerasan Seksual Menurut KUHP dan RUU Penghapusan Kekerasan Seksual
}

\author{
Suci Mahabbati ${ }^{1}$ dan Isna Kartika Sari ${ }^{2}$ \\ ${ }^{1}$ Institut Agama Islam Negeri (LAIN) Kerinci \\ ${ }^{2}$ Mahasiswa Magister Ilmu Hukum Universitas Airlangga \\ e-mail: sucimahabbati@iainkerinci.ac.id
}

\begin{abstract}
ABSTRAK. Dewasa ini, bentuk-bentuk kekerasan seksual semakin berkembang. Aturan hukum yang ada saat ini belum cukup mengatur terkait kekerasan seksual tersebut. Maka dibentuk Rancangan Undang-Undang Penghapusan Kekerasan Seksual untuk mengakomodasi perlindungan hukum terhadap kekerasan seksual di Indonesia. Studi perbandingan antara Kitab Undang-Undang Hukum Pidana dengan Rancangan Undang-Undang Penghapusan Kekerasan Seksual ini bertujuan untuk mereformasi aturan hukum terkait kekerasan seksual yang ada di Indonesia. Metode yang digunakan penulis adalah analytical method, yaitu memulai studi perbandingan dengan menganalisis perbedaan yang ada di antara Kitab Undang-Undang Hukum Pidana terkait kekerasan seksual dengan Rancangan Undang-Undang Penghapusan Kekerasan Seksual. Rancangan Undang-Undang Penghapusan Kekerasan Seksual dipilih sebagai pembanding karena RUU ini dibuat untuk menjangkau kekerasan seksual yang bentuknya terus berkembang di Indonesia. Akan tetapi kehadiran RUU ini menimbulkan polemik di tengah masyarakat. Oleh karena itu, perbedaan kedua aturan ini perlu dianalisis agar dapat diketahui solusi terbaik di antara keduanya. Rancangan Undang-Undang Penghapusan Kekerasan Seksual merupakan aturan yang berperspektif korban. Rancangan Undang-Undang Penghapusan Kekerasan Seksual juga merumuskan upaya pencegahan dalam kekerasan seksual. Karena pencegahan kekerasan seksual merupakan hal yang sangat penting dalam upaya menghapus kekerasan seksual. Dalam rangkaian penanggulangan dan upaya penghapusan kekerasan seksual, seluruh sektor termasuk masyarakat memiliki peran dalam penghapusan kekerasan seksual. Dari hasil studi perbandingan ini dapat disimpulkan bahwa Rancangan Undang-Undang Penghapusan Kekerasan Seksual dapat mengakomodasi penghapusan kekerasan seksual, sehingga sebaiknya dilakukan reformasi hukum untuk menanggulangi kekerasan seksual di Indonesia.
\end{abstract}

Kata kunci: hukum pidana, rancangan undang-undang, kekerasan seksual. 


\section{PENDAHULUAN}

Kekerasan seksual menjadi momok yang menakutkan, khususnya bagi perempuan dan anak. Perempuan dan anak sering kali dianggap sebagai objek atau sasaran karena dianggap lebih lemah. Sulit untuk menjalankan aktivitas dengan aman dan nyaman karena selalu dibayangi ketakutan. Terlebih tidak hanya orang asing yang tega melakukan kekerasan seksual. Tidak menutup kemungkinan orang-orang terdekat dapat melakukan perbuatan keji tersebut.

Menurut Catatan Tahunan (CATAHU) Komnas Perempuan Tahun 2018, kekerasan seksual dengan pelaku orang terdekat yang masih memiliki hubungan keluarga (incest) merupakan kasus yang paling banyak dilaporkan yakni sebanyak 1.210 kasus. Kedua adalah kasus perkosaan sebanyak 619 kasus. Kemudian persetubuhan/eksploitasi seksual sebanyak 555 kasus. Sementara Pada ranah publik dan komunitas kekerasan terhadap perempuan tercatat 3.915 kasus. 64\% di antaranya adalah kekerasan seksual yaitu pencabulan sebanyak 1.136 kasus, perkosaan 762 kasus dan pelecehan seksual 394 kasus. Sementara itu persetubuhan sebanyak 156 kasus. ${ }^{1}$

Mirisnya, kasus-kasus kekerasan seksual ini tidak cukup memberikan gerakan perlawanan yang masif. Padahal korban kekerasan seksual merasakan penderitaan yang luar biasa. Tidak hanya secara fisik, namun juga psikisnya yang terguncang dan dapat menimbulkan trauma yang berpengaruh buruk terhadap diri dan kehidupannya. Bahkan korban terkadang terpaksa dua kali menanggung kemalangan. Salah satunya kekerasan seksual yang dialami WA, seorang remaja putri berusia lima belas tahun asal Jambi yang diperkosa hingga hamil oleh kakak kandungnya, AA yang berusia delapan belas tahun. Namun WA tidak hanya menjadi korban kekerasan seksual, tapi juga korban kriminalisasi dan diskriminasi dikarenakan ia melakukan aborsi atas perintah dari ibu keduanya. WA dijatuhi pidana penjara selama enam bulan, sementara sang Kakak dipidana penjara selama dua tahun. ${ }^{2}$

Sebagai warga negara, perempuan dan anak berhak mendapatkan rasa aman dan bebas dari segala bentuk kekerasan sebagaimana telah dijamin oleh Negara yang tercantum dalam Undang-Undang Dasar Negara Republik Indonesia Tahun 1945. Semua bentuk kekerasan, terutama kekerasan seksual, merupakan pelanggaran hak asasi manusia dan kejahatan terhadap martabat kemanusiaan. Korban kekerasan seksual yang didominasi oleh perempuan dan anak harus mendapatkan perlindungan dan pemulihan dari negara. Selain itu, pelaku kekerasan seksual harus mendapatkan hukuman yang setimpal dengan tindak pidana yang dilakukannya dan dijatuhi kewajiban yang berorientasi untuk mencegah pengulangan tindak pidana dan memulihkan korbannya.

Oleh karena itu, Komisi Nasional Anti Kekerasan Terhadap Perempuan (Komnas Perempuan) merekomendasikan hadirnya harmonisasi kebijakan untuk segala bentuk kekerasan terhadap perempuan di Indonesia. Upaya ini bertujuan mengembangkan kondisi yang kondusif bagi penghapusan segala bentuk kekerasan terhadap perempuan dan penegakan hak-hak asasi manusia perempuan di Indonesia. Selain itu juga untuk meningkatkan upaya pencegahan dan penanggulangan segala bentuk kekerasan, termasuk kekerasan seksual. ${ }^{3}$

Setelah hampir empat tahun Komnas Perempuan bersama gerakan masyarakat sipil serta korban memperjuangkan dan mendorong pemerintah agar membentuk regulasi penghapusan

\footnotetext{
${ }^{1}$ Komisi Nasional Anti Kekerasan Terhadap Perempuan, Catatan Tahunan Tentang Kekerasan Terhadap Perempuan: Korban Bersuara, Data Bicara, Sahkan RUU Penghapusan Kekerasan Seksual Sebagai Wujud Komitmen Negara, Jakarta, 6 Maret 2019, h. 1.

${ }^{2}$ Aditya Widya Putri, "2018 Jadi Tahun yang Buruk Bagi Korban Kejahatan Seksual", https://tirto.id/2018-jadi-tahun-yang-buruk-bagi-korban-kekerasan-seksual-dcKw, $31 \quad$ Desember 2018, dikunjungi pada tanggal 19 Mei 2019.

${ }^{3}$ Terdapat dalam Naskah Akademik Rancangan Undang-Undang Tentang Penghapusan Kekerasan Seksual yang dikeluarkan Komisi Nasional Anti Kekerasan Terhadap Perempuan dan Forum Pengada Layanan pada Desember 2017, h. xiii.
} 
kekerasan seksual. Sejak tahun 2014, Rancangan Undang-Undang Penghapusan Kekerasan seksual diusulkan dalam Prolegnas melalui berbagai dialog baik dengan Pemerintah. Namun, baru pada tahun 2016 Rancangan Undang-Undang Penghapusan Kekerasan Seksual masuk dalam daftar Penambahan Prolegnas 2015-2019 sebagai hasil rapat bersama antara DPR RI, DPD RI dan Pemerintah pada bulan Januari 2016. Munculnya berbagai kasus kekerasan seksual yang beruntun seperti teror terhadap perempuan dan anak sehingga sebagai puncaknya, kasus YY di Bengkulu telah membuka pintu dan meyakinkan lembaga legislatif dan eksekutif untuk segera membahas Rancangan Undang-Undang Penghapusan Kekerasan Seksual. ${ }^{4}$

Rancangan Undang-Undang Penghapusan Kekerasan Seksual ini bertumpu pada semakin banyaknya korban dan berkembangnya bentuk-bentuk kekerasan seksual di Indonesia, sementara sistem hukum yang berlaku belum secara sistematis dan menyeluruh mampu mencegah, melindungi, memulihkan dan memberdayakan korban serta menumbuhkan pemahaman dan kesadaran masyarakat untuk menghapuskan kekerasan seksual. Salah satu contohnya, Kitab Undang-Undang Hukum Pidana yang belum mengakomodasi jenis kekerasan seksual dan belum adanya mekanisme hukum yang mempertimbangkan perspektif pengalaman dan perlindungan bagi korban. ${ }^{5}$

Meskipun demikian, Rancangan Undang-Undang Penghapusan Kekerasan Seksual hingga saat ini terus menuai pro dan kontra. Polemik terhadap Rancangan Undang-Undang Penghapusan Kekerasan Seksual ini dipicu oleh adanya cara pandang dalam melihat aturan yang terkandung didalamnya, yaitu perspektif gender dan perspektif moralitas agama. Pihak yang mendukung untuk segera dilakukannya pengesahan terhadap Rancangan Undang-Undang Penghapusan Kekerasan Seksual ini cenderung menggunakan perspektif gender, sementara yang menentang Rancangan Undang-Undang Penghapusan Kekerasan Seksual ini cenderung menggunakan perspektif moralitas agama. ${ }^{6}$

Dalam perspektif feminis, ketimpangan relasi kuasa atau gender yang dikonstruksi dalam struktur sosial, budaya, ekonomi, politik, dan agama yang patriarkis menjadi akar permasalahan kekerasan seksual. Akibatnya, perempuan sebagai individu yang menjadi korban kekerasan seksual tidak memiliki kuasa untuk memberikan perlawanan dalam upaya mendapatkan keadilan. Maka dari itu, dalam perspektif ini kekerasan seksual tidak hanya semata-mata tindak kesusilaan menurut suatu norma budaya atau agama, melainkan juga suatu tindak kejahatan terhadap martabat kemanusiaan. Justru pandangan moral tertentu dapat menghambat penanganan kekerasan seksual. Seperti stigma negatif terhadap kekerasan seksual yang dianggap sebagai sutu aib yang kemudian berujung pada menyalahkan korban (victim blaming).

Di sisi lainnya, kelompok dengan perspektif moralitas agama menganggap Rancangan Undang-Undang Penghapusan Kekerasan Seksual mengesampingkan norma agama karena menggunakan perspektif feminis yang sekuler dari Barat. Dalam perspektif ini, suatu tindakan kejahatan tidak bisa dipisahkan dari normanya. Akar permasalahan dari kekerasan seksual bukan karena adanya ketimpangan relasi gender, tapi tidak berfungsinya lembaga keluarga sehingga bentuk penyelesaiannya harus dikembalikan kepada norma agama dan refungsionalisasi keluarga. ${ }^{8}$

Pihak dengan perspektif moralitas agama menganggap definisi dan bentuk-bentuk "kekerasan seksual" dalam Rancangan Undang-Undang Penghapusan Kekerasan Seksual ini tidak tepat. Karena menyiratkan adanya "keterpaksaan" dalam tindakannya. Sementara persoalannya bukan pada adanya "keterpaksaan" ataupun "persetujuan" dalam tindakan tersebut, melainkan

${ }^{4}$ Ibid.

${ }^{5}$ Afifurrochman Sya'rani, https://crcs.ugm.ac.id/perspective/13864/ruu-penghapusan-kekerasanseksual-mengapa-dipermasalahkan.html, 12 Februari 2019, dikunjungi pada 19 Mei 2019.

${ }^{6} \mathrm{Ibid}$.
${ }^{7} \mathrm{Ibid}$.
${ }^{8} \mathrm{Ibid}$. 
karena tindakan tersebut memang tidak diperbolehkan dalam agama. Jika tolok ukurnya seperti itu, maka tindakan seksual yang didasari dengan "persetujuan" terkesan diperbolehkan dalam Rancangan Undang-Undang Penghapusan Kekerasan Seksual. Mereka mengusulkan istilah "kekerasan seksual" diganti dengan "kejahatan seksual". Dengan begitu akan lebih sesuai dengan norma agama dan tindakan-tindakan seperti prostitusi, zina, aborsi dan praktik homoseksual diartikan sebagai sebuah kejahatan berdasarkan norma agama yang harus dilarang sepenuhnya.'

Pihak dengan perspektif gender merasa bahwa penggunaan istilah 'kekerasan seksual' sudah tepat. Bagi mereka timpangnya relasi kuasa adalah akar permasalahan gender yang dapat menyebabkan penyalahgunaan kuasa oleh pelaku sehingga membuatnya melakukan kekerasan dan paksaan terhadap korban. Kekerasan seksual bahkan juga dapat terjadi dalam lingkungan keluarga. Dalam naskah akademik Rancangan Undang-Undang Penghapusan Kekerasan Seksual, definisi "kekerasan seksual" tidak menafikan bahwa kekerasan seksual juga merupakan suatu tindak kejahatan. ${ }^{10}$

Berdasarkan uraian di atas, kiranya perlu dilakukan studi perbandingan antara Kitab Undang-Undang Hukum Pidana terkait kekerasan seksual dengan Rancangan Undang-Undang Penghapusan Kekerasan Seksual.

\section{TUJUAN}

Dewasa ini, bentuk-bentuk kekerasan seksual semakin berkembang. Aturan hukum yang ada saat ini belum cukup mengatur terkait kekerasan seksual tersebut. Maka dibentuk Rancangan UndangUndang Penghapusan Kekerasan Seksual untuk mengakomodasi perlindungan hukum terhadap kekerasan seksual di Indonesia.

Studi perbandingan antara Kitab Undang-Undang Hukum Pidana dengan Rancangan Undang-Undang Penghapusan Kekerasan Seksual ini bertujuan untuk mereformasi aturan hukum terkait kekerasan seksual yang ada di Indonesia.

\section{METODOLOGI}

Metode yang digunakan penulis adalah analytical method, yaitu memulai studi perbandingan dengan menganalisis perbedaan yang ada di antara Kitab Undang-Undang Hukum Pidana terkait kekerasan seksual dengan Rancangan Undang-Undang Penghapusan Kekerasan Seksual.

Rancangan Undang-Undang Penghapusan Kekerasan Seksual dipilih sebagai pembanding karena RUU ini dibuat untuk menjangkau kekerasan seksual yang bentuknya terus berkembang di Indonesia. Akan tetapi kehadiran RUU ini menimbulkan polemik di tengah masyarakat. Oleh karena itu, perbedaan kedua aturan ini perlu dianalisis agar dapat diketahui solusi terbaik di antara keduanya.

\section{PEMBAHASAN}

1. Perbandingan external law antara Kitab Undang-Undang Hukum Pidana terkait kekerasan seksual dengan Rancangan Undang-Undang Penghapusan Kekerasan Seksual

\begin{tabular}{|c|c|c|c|}
\hline & & KUHP & RUU PKS \\
\hline Jenis & kekerasan & $\begin{array}{l}\text { a. Perkosaan } \\
\text { b. Pencabulan }\end{array}$ & $\begin{array}{l}\text { a. Pelecehan seksual } \\
\text { b. Eksploitasi seksual }\end{array}$ \\
\hline
\end{tabular}

${ }^{9}$ Ibid.

${ }^{10} \mathrm{Ibid}$. 


\begin{tabular}{lll}
\hline seksual & & c. Pemaksaan kontrasepsi \\
& d. Pemaksaan aborsi \\
& e. Perkosaan \\
& f. Pemaksaan perkawinan \\
& g. Pemaksaan pelacuran \\
h. Perbudakan seksual & i. Penyiksaan seksual
\end{tabular}

2. Perbandingan internal law antara Kitab Undang-Undang Hukum Pidana terkait kekerasan seksual dengan Rancangan Undang-Undang Penghapusan Kekerasan Seksual

Pada dasarnya terdapat lima belas jenis kekerasan seksual sesuai dengan hasil identifikasi dan kajian pengalaman penanganan kasus kekerasan seksual yang dilakukan oleh Komnas Perempuan dan Forum Pengadaan Layanan. Akan tetapi hanya jenis kekerasan seksual yang memiliki unsur subjektif dan unsur objektif yang dapat dikriminalisasi sebagai tindak pidana. Praktik tradisi bernuansa seksual yang mendiskriminasi dan membahayakan perempuan di Indonesia termasuk salah satu bentuk kekerasan seksual yang tidak diselesaikan dengan hukum pidana.

Meskipun tidak seluruhnya dari 15 jenis kekerasan seksual tersebut dapat digolongkan sebagai tindak pidana, namun Rancangan Undang-Undang Penghapusan Kekerasan Seksual ini menginginkan adanya upaya perubahan cara pandang dan pola pikir melalui pendidikan dan penyebarluasan informasi mengenai persamaan gender tanpa mendiskriminasi perempuan dan memperbaiki praktik-praktik budaya serta stigma dalam masyarakat yang merugikan perempuan.

Rancangan Undang-Undang Penghapusan Kekerasan Seksual adalah ketentuan khusus (lex specialis) dari Kitab Undang-Undang Hukum Pidana. Karena Rancangan Undang-Undang Penghapusan Kekerasan Seksual mengatur tindak pidana kekerasan seksual yang tidak diatur dalam Kitab Undang-Undang Hukum Pidana. Terdapat sembilan jenis tindak pidana 
kekerasan seksual yang dirumuskan dalam Rancangan Undang-Undang Penghapusan Kekerasan Seksual, yaitu:

a. Pelecehan seksual

b. Eksploitasi seksual

c. Pemaksaan kontrasepsi

d. Pemaksaan aborsi

e. Perkosaan

f. Pemaksaan perkawinan

g. Pemaksaan pelacuran

h. Perbudakan seksual

i. Penyiksaan seksual

Rancangan Undang-Undang Penghapusan Kekerasan Seksual juga merumuskan upaya pencegahan dalam kekerasan seksual. Karena pencegahan kekerasan seksual merupakan hal yang sangat penting dalam upaya menghapus kekerasan seksual. Pencegahan kekerasan seksual harus dilakukan secara komprehensif dan terpadu, terintegrasi antar sektor, serta dilakukan di semua level pemerintahan dan peran dari masyarakat.

Upaya pencegahan kekerasan seksual dalam Rancangan Undang-Undang Penghapusan Kekerasan Seksual ini dimasukkan dalam berbagai bidang, yaitu:

a. Bidang Pendidikan

Pencegahan di bidang pendidikan mencakup mengintegrasikan materi mengenai kekerasan seksual dan kesehatan reproduksi dalam kurikulum, nonkurikulum, ekstrakulikuler, dan materi pembelajaran. Selain itu juga meningkatkan pengetahuan dan keterampilan tenaga pendidik dan pengelola lembaga pendidikan, mulai dari lembaga pendidikan usia dini hingga lembaga pendidikan tinggi mengenai deteksi dini kekerasan yang terjadi, penanganan awal, konseling, pengasuhan anak, serta menerapkan kebijakan anti kekerasan seksual di semua lingkungan pendidikan. Lembaga pendidikan juga perlu meningkatkan kerja sama dengan orang tua, masyarakat, lembaga pendamping korban, LSM, dan aparatur penegak hukum.

b. Bidang Infrastruktur, Pelayanan Publik, dan Tata Ruang

Pencegahan kekerasan seksual juga harus diintegrasikan dengan kebijakan infrastruktur, pelayanan publik, tata ruang, dan pemukiman. Hal ini terkait dengan sarana fisik. Pembangunan infrastruktur, pelayanan publik, tata ruang, dan pemukiman harus mempertimbangkan potensi timbulnya kekerasan seksual di tempat-tempat umum.

c. Bidang Pemerintahan dan Tata Kelola Kelembagaan

Selama ini pencegahan kekerasan seksual hanya berkonsentrasi pada masyarakat. Padahal pencegahan kekerasan seksual di bidang pemerintahan dan tata kelola kelembagaan juga merupakan hal penting. Karena akan berdampak pada kebijakan, program dan anggaran yang disusun agar mampu mendukung upaya penghapusan kekerasan seksual. Materi kekerasan seksual harus dimasukkan dalam kurikulum pendidikan dan pelatihan dalam lembaga yang dikelola oleh negara, serta membangun sistem pendataan dan pelaporan yang terintegrasi.

d. Bidang Ekonomi

Pencegahan kekerasan seksual juga harus dilakukan di bidang ekonomi untuk mendorong tanggung jawab pelaku usaha dalam mencegah terjadinya kekerasan seksual. Banyak kasus kekerasan seksual, terutama pelecehan dan eksploitasi seksual terjadi di tempat kerja. Upaya-upaya pencegahan yang harus dilakukan adalah menerapkan kebijakan anti kekerasan, menyediakan informasi tentang kekerasan seksual, deteksi sini terjadinya kekerasan seksual, dan menerapkan infrastruktur usaha yang menutup peluang terjadinya kekerasan seksual di tempat usaha dan/atau perusahaan.

e. Bidang Sosial, Agama dan Budaya 
Upaya pencegahan kekerasan seksual di bidang sosial, agama dan budaya dapat dilakukan dengan menyediakan informasi kepada media massa, lembaga masyarakat, lembaga keagamaan, dan lembaga adat. Lembaga-lembaga tersebut juga harus menerapkan kebijakan terkait penghapusan kekerasan seksual. Selain itu, keluarga dan orang tua juga harus meningkatkan pengetahuan dan kemampuannya yang mencakup deteksi dini dan penanganan awal jika kekerasan seksual terjadi.

Di masyarakat terdapat stigma negatif terhadap korban kekerasan seksual. Untuk itu, Rancangan Undang-Undang Penghapusan Kekerasan Seksual mengatur perlindungan dan pemenuhan hak bagi korban, keluarga korban, dan saksi. Perlindungan dan pemenuhan hak korban ini bertujuan untuk mengubah kondisi korban menjadi lebih adil, bermartabat dan sejahtera.

Selain pencegahan kekerasan seksual, Rancangan Undang-Undang Penghapusan Kekerasan Seksual juga mengatur mengenai pemantauan upaya penghapusan kekerasan seksual. Pemantauan kekerasan seksual ini untuk mengukur sejauh mana negara sebagai penanggung jawab dalam melakukan perlindungan, pemenuhan, dan penghormatan terhadap hak asasi manusia, khususnya hak-hak korban kekerasan seksual.

Pemantauan upaya penghapusan kekerasan seksual ini juga berguna untuk mengidentifikasi secara jelas pola-pola kekerasan seksual, dampak yang ditimbulkan, hambatan dalam pemenuhan hak-hak korban, atau potensi terjadinya pengabaian dan diskriminasi yang dialami korban. Pemantauan ini merupakan kewajiban negara yang harus dilaksanakan mulai dari upaya pencegahan hingga kebijakan mengenai penghapusan kekerasan seksual benarbenar dilaksanakan.

Pemerintah juga harus membentuk mekanisme khusus pemantauan pelaksanaan Undang-Undang Penghapusan Kekerasan Seksual ini nantinya. Mekanisme khusus ini untuk memastikan kebijakan, program, anggaran, dan tindakan lembaga-lembaga negara, serta korporasi dan lembaga masyarakat menjamin terwujudnya penghapusan kekerasan seksual. Mekanisme pemantauan tersebut akan diselenggarakan oleh Komisi Nasional Anti Kekerasan Terhadap Perempuan.

Dalam hal pemidanaan, Rancangan Undang-Undang Penghapusan Kekerasan Seksual merumuskan ancaman pidana pokok berupa pidana penjara dan pidana rehabilitasi khusus. Pidana rehabilitasi khusus ditujukan kepada pelaku kekerasan seksual yang berusia di bawah empat belas tahun atau pelaku kekerasan seksual yang sifatnya tidak ada kontak tubuh antara pelaku dan korban (no body contact).

Pada dasarnya, rehabilitasi bagi pelaku sudah dilakukan oleh lembaga pemasyaraktan. Akan tetapi, rehabilitasi tersebut kurang maksimal karena lebih kepada mempersiapkan terpidana untuk kembali dan dapat diterima oleh masyarakat. Dalam kasus kekerasan seksual, rehabilitasi khusus dilakukan tidak hanya untuk mempersiapkan terpidana kembali dan diterima di masyarakat, tapi yang terpenting adalah agar cara pandang, cara pikir, dan perilaku seksual terpidana berubah dalam melihat perempuan dan memahami untuk tidak melakukan kekerasan seksual sehingga terpidana tidak akan mengulangi perbuatannya.

Selain pidana pokok, Rancangan Undang-Undang Penghapusan Kekerasan Seksual juga merumuskan pidana tambahan, meliputi:
a. Restitusi
b. perampasan keuntungan yang diperoleh dari tindak pidana
c. kerja sosial
d. pembinaan khusus
e. pencabutan hak asuh
f. pencabutan hak politik 
g. pencabutan hak menjalankan pekerjaan tertentu

h. pencabutan jabatan atau profesi

i. pengumuman putusan hakim

Selain pidana tambahan, juga terdapat ketentuan pidana dan sanksi administrasi terhadap petugas atau aparatur penegak hukum yang melanggar kewajiban yang telah ditetapkan. Sanksi administrasi dijatuhkan apabila lembaga negara, institusi penegak hukum, atau petugas lembaga pengada layanan lalai dalam menjalankan tanggung jawabnya terkait penanganan, perlindungan, dan pemulihan korban kekerasan seksual.

Berbeda dengan Kitab Undang-Undang Hukum Pidana yang hanya mengatur pidana penjara dalam jangka waktu maksimal, Rancangan Undang-Undang Penghapusan Kekerasan Seksual mengatur pemidanaan penjara minimal dan maksimal untuk sebagian besar tindak pidana kekerasan seksual. Hal ini didasari oleh pengalaman dan fakta tentang pemidanaan yang sudah ada selama ini. Tidak adanya penetapan pidana penjara minimal, mengakibatkan putusan yang dijatuhkan kepada hakim seringkali sangat rendah bahkan hanya setengah dari tuntutan jaksa penuntut umum.

Tujuan pemidanaan dalam Rancangan Undang-Undang Penghapusan Kekerasan Seksual ini adalah untuk memulihkan keadilan masyarkat, khususnya korban. Prinsip yang harus dikedepankan dalam penyelesaian kasus kekerasan seksual adalah bahwa tindakan atau upaya yang dilakukan di luar hukum untuk menyelesaikan kasus tersebut tidak menghilangkan tindak pidananya. Rancangan Undang-Undang Penghapusan Kekerasan Seksual membedakan delik menjadi dua, yaitu delik aduan dan delik umum. Delik aduan untuk jenis kekerasan seksual berupa pelecehan seksual.

Ancaman pemidanaan terhadap sembilan jenis tindak pidana kekerasan seksual meliputi pemidanaan masing-masing bentuk kekerasan seksual secara umum dan terkait dengan bagaimana cara melakukan kekerasan seksual, pada siapa dilakukannya kekerasan seksual, kapan dan dalam situasi apa kekerasan seksual tersebut dilakukan, dan dampak apa yang ditimbulkan dari kekerasan seksual itu pada korbannya. Perumusan ketentuan pidana dalam hal ini mengacu pada Kitab Undang-Undang Hukum Pidana terkait dengan pasal pemberatan, penyertaan, dan lain-lain. Namun juga disesuaikan dengan situasi dan kondisi yang terjadi dalam tidak pidana kekerasan seksual.

\section{TEMUAN}

Hukum sebagai suatu sistem terdiri dari substansi hukum, struktur hukum, dan budaya hukum yang saling berinteraksi. ${ }^{11}$ Saat ini aturan hukum yang terdapat dalam Kitab Undang-Undang Pidana tidak cukup mengatur terkait kekerasan seksual. Terbatasnya unsur-unsur dan definisi terhadap kekerasan seksual mengakibatkan keadilan bagi korban sulit terpenuhi. Bahkan pada beberapa kasus korban dikriminalisasi dan harus mendapatkan hukuman. Sementara Rancangan Undang-Undang Penghapusan Kekerasan Seksual secara terpadu dan komprehensif memuat aturan untuk menanggulangi kekerasan seksual agar dapat dihapuskan seluruhnya. Mulai dari pencegahan, penanganan, perlindungan, hingga pemulihan korban.

Dari struktur hukum, juga menggambarkan tidak memadainya penanganan kasus kekerasan seksual dan perlindungan korban. Kepolisian, Kejaksaan, dan Pengadilan belum sepenuhnya memberikan perlakuan khusus dalam penanganan kasus kekerasan seksual. Seperti masih belum memadainya fasilitas untuk pemeriksaan korban di ruang yang terpisah, masih terdapat aparatur penegak hukum yang cara pandangnya tidak berperspektif korban dalam

${ }^{11}$ Lawrence M. Friedman, The Legal System: A Social Science Perspective, Russell Sage Foundation, New York:1975, hlm.14. 
memahami substansi hukum untuk memahami kebutuhan korban agar siap dalam memberikan keterangan. ${ }^{12}$ Sementara Rancangan Undang-Undang Penghapusan Kekerasan Seksual telah merumuskan penanggung jawab dan kewajiban yang harus dilaksanakan dalam penanggulangan kekerasan seksual. Bahkan telah diatur sanksi pidana dan sanksi administratif bagi pihak-pihak yang lalai dan tidak memenuhi kewajibannya dalam penanggulangan kekerasan seksual ini.

Dari budaya hukum pun, masyarakat belum berperspektif korban. Masih terdapat stigma di masyarakat bahwa kekerasan seksual terjadi akibat perilaku dari korban sendiri. Bahkan keluarga dan orang tua korban kekerasan seksual ada yang beranggapan bahwa kekerasan seksual yang dialami anaknya adalah sebuah aib. Sehingga korban harus menanggung penderitaannya sendiri dan tidak ada yang mendukungnya. Oleh karena itu, Rancangan Undang-Undang Penghapusan Kekerasan Seksual merupakan aturan yang berperspektif korban. Dalam rangkaian penanggulangan dan upaya penghapusan kekerasan seksual, seluruh sektor termasuk masyarakat memiliki peran dalam penghapusan kekerasan seksual.

Dari hasil studi perbandingan ini dapat disimpulkan bahwa Rancangan Undang-Undang Penghapusan Kekerasan Seksual dapat mengakomodasi penghapusan kekerasan seksual, sehingga sebaiknya dilakukan reformasi hukum untuk menanggulangi kekerasan seksual di Indonesia.

\section{REFERENSI}

Friedman, Lawrence M. The Legal System: A Social Science Perspective, Russell Sage Foundation, New York.

Komisi Nasional Anti Kekerasan Terhadap Perempuan, Catatan Tabunan Tentang Kekerasan Terhadap Perempuan: Korban Bersuara, Data Bicara, Sabkan RUU Penghapusan Kekerasan Seksual Sebagai Wujud Komitmen Negara, Jakarta.

Komnas Perempuan, Sistem Peradilan Pidana Terpadu yang Berkeadilan Jender dalam Penanganan Kasus Kekerasan terhadap Perempuan, Kertas Kebijakan Serial Publikasi Kemitraan Perempuan dan Penegak Hukum, Jakarta, Komnas Perempuan.

Naskah Akademik Rancangan Undang-Undang Tentang Penghapusan Kekerasan Seksual yang dikeluarkan Komisi Nasional Anti Kekerasan Terhadap Perempuan dan Forum Pengada Layanan pada Desember 2017.

Afifurrochman Sya'rani, https://crcs.ugm.ac.id/perspective/13864/ruu-penghapusan-kekerasanseksual-mengapa-dipermasalahkan.html, 12 Februari 2019, dikunjungi pada 19 Mei 2019.

Profil Komnas Perempuan, https://www.komnasperempuan.go.id/about-profile-komnasperempuan, dikunjungi pada 19 Mei 2019.

Putraningsih, Titik, "Pertunjukan Tari: Sebuah Kajian Perspektif Gender", http://staffnew.uny.ac.id/upload/132061380/penelitian/Jurnal+Tr+Perspektif+gender. pdf, dikunjungi pada 19 Mei 2019.

Putri, Aditya Widya, "2018 Jadi Tahun yang Buruk Bagi Korban Kejahatan Seksual", https://tirto.id/2018-jadi-tahun-yang-buruk-bagi-korban-kekerasan-seksual-dcKw, $\quad 31$ Desember 2018, dikunjungi pada tanggal 19 Mei 2019.

\footnotetext{
${ }^{12}$ Komnas Perempuan, Sistem Peradilan Pidana Terpadu yang Berkeadilan Jender dalam Penanganan Kasus Kekerasan terhadap Perempuan, Kertas Kebijakan Serial Publikasi Kemitraan Perempuan dan Penegak Hukum, Jakarta, Konas Perempuan, 2005, h. 38.
} 